\title{
Toxic shock syndrome caused by Streptococcus dysgalactiae subsp. equisimilis in a Mexican preschool patient
}

\author{
Lorena Rodríguez-Muñoz ${ }^{*}$, Óscar García-Galván ${ }^{1}$ Miguel Á. González-Soto, Gabriela Echániz-Avilés² \\ and Fortino Solórzano-Santos ${ }^{3}$ \\ ${ }^{1}$ Hospital del Niño, Saltillo, Coahuila; ${ }^{2}$ Departamento de Evaluación de Vacunas, Instituto Nacional de Salud Pública, Cuernavaca, Morelos; ${ }^{3}$ Unidad \\ de Investigación Medicina Basada en Evidencias, Hospital Infantil de México Federico Gómez, Mexico City. Mexico
}

\begin{abstract}
Background: Severe infections due to Streptococcus dysgalactiae subsp. equisimilis (SDSE) have been identified in adults and may cause toxic shock syndrome, although with a low frequency. Case report: A preschool-age female patient, who started with an upper respiratory tract infection developing a gradual deterioration in the following three days, is described. She was admitted to the hospital in severe conditions, with tachypnea, tachycardia (200/min), hypotension (blood pressure $68 / 40 \mathrm{mmHg}$ ), capillary refill of $7 \mathrm{~s}$, and erythematous maculopapular rash in thorax, abdomen and lower extremities. She received intensive management with an inadequate response. Furthermore, she developed multiple organ failure and died $8 \mathrm{~h}$ after admission. The blood culture was positive for S. dysgalactiae subsp. equisimilis. Conclusions: SDSE is a rare pathogen in children. In Mexico, cases of SDSE have not been reported probably due to an inaccurate identification. Mexican pediatricians should be alert to this situation..
\end{abstract}

Key words: Streptococcus dysgalactiae. Streptococcal toxic shock syndrome. Severe streptococcal infection.

\section{Síndrome de choque tóxico por Streptococcus dysgalactiae subsp. equisimilis en un paciente preescolar mexicano}

\section{Resumen}

Introducción: En adultos, se han identificado infecciones graves por Streptococcus dysgalactiae subsp. equisimilis (SDSE), que pueden causar el síndrome de choque tóxico causado por SDSE, aunque es de baja frecuencia. Caso clínico: Paciente de sexo femenino en edad preescolar. Comenzó con una infección del tracto respiratorio superior, y desarrolló un deterioro gradual en los siguientes tres días. Ingresó en el hospital en condiciones graves, con taquipnea, taquicardia (200/min), hipotensión (tensión arterial, TA 68/40 mmHg), llenado capilar de 7 s y erupción maculopapular eritematosa en el tórax, abdomen y extremidades inferiores. Recibió manejo intensivo, sin una buena respuesta. Posteriormente, desarrolló datos de falla orgánica múltiple y murió $8 \mathrm{~h}$ después de su ingreso. El hemocultivo fue positivo para $S$. dysgalactiae subsp. equisimilis. Conclusiones: EI SDSE es un patógeno raro en los niños. En México, no se han reportado casos de SDSE probablemente debido a una identificación errónea. Los pediatras mexicanos deben estar atentos a esta situación.

Palabras clave: Streptococcus dysgalactiae. Síndrome de choque tóxico estreptocócico. Infección estreptocócica grave.

Available online: 20-09-2019 


\section{Introduction}

Beta-hemolytic groups A (Streptococcus pyogenes) and B (Streptococcus agalactiae) streptococci of the Lancefield classification are considered etiological agents of mild to severe infectious diseases. S. pyogenes causes purulent tonsillitis, skin and soft tissue infections, scarlet fever, non-cutaneous infections (myositis, myonecrosis, pharyngitis, pneumonia, postpartum endometritis), and streptococcal toxic shock syndrome (STSS). S. agalactiae is most commonly associated with perinatal infections ${ }^{1-3}$.

Different reports have shown other streptococci groups (C, G, F, and $L$ ) as a frequent cause of human infections. In recent years, groups $C$ and $G$ streptococci (GCS-GGS) have emerged as serious pathogens. Moreover, their frequency is similar or could exceed group A streptococcus (GAS) as a cause of invasive diseases in some countries ${ }^{4-7}$.

Group G includes Streptococcus dysgalactiae subsp. equisimilis (SDSE), Streptococcus anginosus, and Streptococcus canis ${ }^{4-6}$. Vandamme et al. ${ }^{8}$ proposed two main subspecies of S.dysgalactiae in 1996: S. dysgalactiae subsp. equisimilis (SDSE) (associated with human infections) and S. dysgalactiae subsp. dysgalactiae (SDSD). Due to its agglutination reaction when exposed to Lancefield group $C$ and $G$ antigens, SDSE has been considered within both B-hemolytic groups $C$ (GCS) and G (GGS).

During the present century, an increase in case reports of severe infections by SDSE has been described worldwide, and a similar frequency with those caused by groups $A$ and $B$ in some countries. Therefore, SDSE invasive diseases are now considered an emerging health problem ${ }^{4-7,9,10}$. Some authors define an SDSE invasive infection when these bacteria are isolated from a sterile site or isolated on several occasions from non-sterile sites in a patient with necrotizing fasciitis or streptococcal toxic shock syndrome ${ }^{10,11}$.

The most severe infections caused by SDSE (cellulitis, pneumonia, urosepsis, bacteremia, osteoarticular infections, skin and soft tissue infections, and STSS) are observed in the adult population, particularly those over 60 years of age. These infections are infrequent in children, in which STSS is a rare event ${ }^{7,9-13}$.

In this report, a clinical case of a severe infection caused by SDSE in a preschool child that fulfilled streptococcal toxic shock syndrome criteria is presented.

\section{Clinical case}

A 3-year-old previously healthy female started her condition with a history of three days with malaise, fever $\left(38^{\circ} \mathrm{C}\right)$, hyporexia, irritability, and vomiting. An upper respiratory tract infection of viral etiology was diagnosed, and symptomatic treatment was prescribed. As the patient showed a poor evolution, she was brought to the hospital due to a state of altered consciousness in the last hours. At admission, she showed adequate alertness and awareness with a Glasgow scale of 14. However, during the first hours, the Glasgow scale score decreased in three 3 points. Physical examination revealed a red maculopapular rash (thorax, abdomen and lower extremities), tachypnea, tachycardia (200/min), hypotension (BP $68 / 40 \mathrm{mmHg}$ ), capillary filling of $7 \mathrm{~s}$; in thorax auscultation, right basal hypoventilation was detected. Intensive care management included crystalloid and vasoactive amines administration, orotracheal intubation, and mechanical ventilation. Ceftriaxone and vancomycin were started. Due to neurological deterioration, neuroinfection was suspected and a lumbar puncture was requested; however, it was delayed due to the patient's hemodynamic instability. Despite the intensive management, tachycardia and hypotension persisted. Eight hours after admission, she presented cardiorespiratory arrest with no response to advanced resuscitation maneuvers and died.

Admission laboratory tests reported $13.3 \mathrm{~g} / \mathrm{dl}$ hemoglobin, $39.6 \%$ hematocrit, 3,210/mm 3 leukocytes, $73 \%$ neutrophils, $16 \%$ lymphocytes, $6 \%$ monocytes, $5 \%$ eosinophils, $17 \%$ bands, $323,000 / \mathrm{mm}^{3}$ platelets. C-reactive protein, $390 \mathrm{mg} / \mathrm{l} ; \mathrm{Na}^{+}, 130 \mathrm{mEq} / \mathrm{l} ; \mathrm{K}^{+}, 5.48 \mathrm{mEq} / \mathrm{l}$; $\mathrm{Cl}^{-}, 95.4 \mathrm{mEq} / \mathrm{l}$. Total protein, $4.4 \mathrm{~g} / \mathrm{dl}$; albumin, $2.5 \mathrm{~g} / \mathrm{dl}$; globulin, $1.9 \mathrm{~g} / \mathrm{dl}$; DB (direct bilirubin), $0.4 \mathrm{mg} / \mathrm{dl}$; IB (indirect bilirubin), $0.10 \mathrm{mg} / \mathrm{dl}$; GOT (glutamic-oxalacetic transaminase), $213 \mathrm{U} / \mathrm{l}$; GPT (glutamic-pyruvic transaminase), $97 \mathrm{U} / \mathrm{l}$; ALP (alkaline phosphatase), $141 \mathrm{U} / \mathrm{l}$; LDH (lactate dehydrogenase), $1855 \mathrm{U} / \mathrm{l}$. Blood urea nitrogen, $49.8 \mathrm{mg} / \mathrm{dl}$; creatinine, $1.4 \mathrm{mg} / \mathrm{dl}$; urea, $109.3 \mathrm{mg} / \mathrm{dl}$. Venous gasometry showed pH 6.8, $\mathrm{pCO}_{2}$ (partial $\mathrm{CO}_{2}$ pressure) $84, \mathrm{PO}_{2}$ (partial $\mathrm{O}_{2}$ pressure) 45 , $\mathrm{HCO}_{3} 19.8$, BEb (base excess) - $11.8, \mathrm{O}_{2}$ saturation 53 , lactate $2 \mathrm{mmol} / \mathrm{l}$. Coagulation tests were not performed. At admission, two blood cultures were collected.

Blood cultures were processed in the Bact/Alert system $^{\circledR}$ (bioMérieux Mexico). Subsequently, bacterial identification was made with the Vitek ${ }^{\circledR} 2$ system (bioMérieux Mexico). Results from blood cultures were obtained $48 \mathrm{~h}$ after the patient died, and $S$. pyogenes was identified. As part of the surveillance system for streptococcal infections, the strain was referred to the National Institute of Public Health, where it was sent for MALDI-TOF system confirmation. The results confirmed Streptococcus dysgalactiae subspecies equisimilis ${ }^{14,15}$. 


\section{Discussion}

The case of a previously healthy preschool child, with an upper respiratory tract infection that in a short time developed toxic shock syndrome (hypotension, erythematous macular rash, and multi-organ failure: renal and hepatic dysfunction and acute respiratory distress syndro$\mathrm{me}$ ), and a rapidly lethal outcome is presented. The initial bacterial identification of the blood culture was $S$. pyogenes, which was changed to $\mathrm{S}$. dysgalactiae subspecies equisimilis according to MALDI-TOF results. The VITEK 2 system, which is considered as one of the most reliable systems, is the most commonly used bacterial identification method in clinical microbiology laboratories. Several authors have found that the Vitek 2 system has a lower identification capacity than the MALDI-TOF MS system in the identification of beta-hemolytic Streptococcus (BHS), particularly in the discrimination of $S$. dysgalactiae. It is considered that the MALDI-TOF MS system can be a powerful and cost-effective tool for the identification of $\mathrm{BHS}$ in routine clinical microbiology laboratories ${ }^{16,17}$.

To the present date, no reports of serious infections caused by $S$. dysgalactiae subspecies equisimilis can be found in Mexico. Since the late 1980s, STSS caused by $S$. pyogenes (group A streptococcus) has become a serious problem in many countries. It is a severe invasive infection characterized by the sudden onset of shock, multiorgan failure, and high mortality. Although STSS is mainly caused by $S$. pyogenes, the group $G$ streptococcus, identified as $S$. dysgalactiae subsp. equisimilis (SDSE), has also been associated with STSS. The first cases of STSS caused by SDSE were reported in the $90 \mathrm{~s}$ in Japan ${ }^{18}$. Currently, the number of reports have been increasing worldwide. More than 50 types of the emm gene in SDSE have been found. These genes encode the M protein, which is the main virulence factor of GAS that could be associated with the pathogenesis of streptococcal infections and could be responsible for the development of STSS ${ }^{19}$.

More than $90 \%$ of cases of bacteremia and invasive diseases caused by $S$. dysgalactiae subsp equisimilis are detected in elderly patients suffering from some comorbidity (diabetes mellitus, cardiovascular diseases, immunosuppression, cancer), but pediatric infections are scarce. The primary site of the infection cannot be identified in all cases. The patient in this report started with an upper respiratory tract infection that led to the lethal form of toxic shock syndrome in a few days. In a recent study, SDSE has been identified in $2 \%$ of cases of acute pharyngitis, predominantly in schoolchildren ${ }^{20}$, apparently with a favorable course.
According to the medical literature, the participation of SDSE in Mexico has not been reported. However, the identification of this species in a preschool patient suggests that it is probably circulating in other areas of the country. It is essential to alert microbiology laboratories and pediatricians to consider that some of the isolates identified as $S$. pyogenes under traditional methods may correspond to $S$. dysgalactiae subspecies equisimilis. Due to the fulminate course of these bacterial infections, it is necessary to improve their appropriate identification.

\section{Ethical disclosures}

Protection of human and animal subjects. The authors declare that no experiments were performed on humans or animals for this study.

Confidentiality of data. The authors declare that they have followed the protocols of their work center on the publication of patient data.

Right to privacy and informed consent. The authors have obtained the written informed consent of the patients or subjects mentioned in the article. The corresponding author has this document.

\section{Conflicts of interest}

The authors declare no conflict of interest.

\section{Funding}

No funding was received.

\section{References}

1. Ikebe T, Tominaga K, Shima T, Okuno R, Kubota H, Ogata K, Working Group for Beta-haemolytic Streptococci in Japan, et al. Increased prevalence of group A streptococcus isolates in streptococcal toxic shock syndrome cases in Japan from 2010 to 2012. Epidemiol Infect. 2015;143:864-72.

2. Lambertsen LM, Ingels $H$, Schønheyder HC, Hoffmann S, Danish Streptococcal Surveillance Collaboration Group 2011. Nationwide laboratory-based surveillance of invasive beta-haemolytic streptococci in Denmark from 2005 to 2011. Clin Microbiol Infect. 2014;20:0216-23.

3. Patras KA, Nizet V. Group B streptococcal maternal colonization and neonatal disease: molecular mechanisms and preventative approaches. Front Pediatr. 2018;6:27.

4. Broyles LN, Van Beneden C, Beall B, Facklam R, Shewmaker PL, Malpiedi P, et al. Population-based study of invasive disease due to $\beta$-hemolytic streptococci of groups other than A and B. Clin Infect Dis. 2009;48:706-12.

5. Liao CH, Liu LC, Huang YT, Teng LJ, Hsueh PR. Bacteremia caused by group G streptococci, Taiwan. Emerg Infect Dis. 2008;14:837-40.

6. Sylvetsky N, Raveh D, Schlesinger Y, Rudensky B, Yinnon AM. Bacteremia due to beta-hemolytic Streptococcus group G: increasing incidence and clinical characteristics of patients. Am J Med. 2002;112:622-6.

7. Brandt C, Spellergerg B. Human infections due to Streptococcus dysgalactiae subspecies equisimilis. Clin Infect Dis. 2009;49:766-72.

8. Vandamme P, Pot B, Falsen E, Kersters K, Devriese LA. Taxonomic study of Lancefield streptococcal groups C, G, and L (Streptococcus dysgalactiae) and proposal of $S$. dysgalactiae subsp. equisimilis subsp. nov. Int J Syst Bacteriol. 1996;46:774-81. 
9. Rantala S. Streptococcus dysgalactiae subsp. equisimilis bacteremia an emerging infection. Eur J Clin Microbiol Infect Dis. 2014;33:1303-10.

10. Watanabe S, Takemoto N, Ogura K, Miyoshi-Akiyama T. Severe invasive streptococcal infection by Streptococcus pyogenes and Streptococcus dysgalactiae subsp. equisimilis. Microbiol Immunol. 2016;60:1-9.

11. Takahashi T, Asami R, Tanabe K, Hirono Y, Nozawa Y, Chiba N, et al. Clinical aspects of invasive infection with Streptococcus dysgalactiae subsp. equisimilis in elderly patients. J Infect Chemother. 2010;16:68-71.

12. Traverso $F$, Blanco A, Villalón $P$, Beratz N, Sáez Nieto JA, Lopardo $H$ National Collaborative Group for the Study of Streptococci and Related Bacteria. Molecular characterization of invasive Streptococcus dysgalactiae subsp. equisimilis. Multicenter study: Argentina 2011-2012. Rev Argent Microbiol. 2016;48:279-89.

13. Baxter M, Morgan M. Streptococcal toxic shock syndrome caused by group G Streptococcus, United Kingdom. Emerg Infect Dis. 2017:23:127-9.

14. Bhavsar SM, Dingle TC, Hamula CL. The impact of blood culture identification by MALDI-TOF MS on the antimicrobial management of pediatric patients. Diagn Microbiol Infect Dis. 2018;92:220-5.

15. Ciszewski M, Zegarski K, Szewczyk EM. Streptococcus dysgalactiae subsp. equisimilis isolated from infections in dogs and humans: are current subspecies identification criteria accurate? Curr Microbiol. 2016; 73:684-8.

16. Cherkaoui A, Emonet S, Fernandez J, Schorderet D, Schrenzel J. Evaluation of matrix-assisted laser desorption ionization-time of flight mass spectrometry for rapid identification of Beta-hemolytic streptococci. J Clin Microbiol. 2011;49:3004-5

17. Besli $Y$, Ayas M, Karatuna O, Akyar I. Comparison of matrix-assisted laser desorption ionization-time of flight mass spectrometry with VITEK2 Gram-positive system for identification of beta-hemolytic Streptococci. J Immunol Clin Microbiol. 2018;3:1-7.

18. Kugi M, Tojo H, Haraga I, Takata T, Handa K, Tanaka K Syndrome similar to toxic shock caused by Streptococcus group G. J Infect. 1998;37:308-9.

19. Ikebe T, Okuno R, Sasaki M, Kanda Y, Otsuka H, Kawahara R, Working Group for Beta-Hemolytic Streptococci in Japan. Molecular characterization and antibiotic resistance of Streptococcus dysgalactiae subspecies equisimilis isolated from patients with streptococcal toxic shock syndrome. J Infect Chemother. 2018;24:117-22.

20. Kakuya $F$, Kinebuchi $T$, Okubo $H$, Matsuo $K$, Kuroda M, Fujiyasu $H$. Acute pharyngitis associated with Streptococcus dysgalactiae subspecies equisimilis in children. Pediatr Infect Dis J. 2018;37:537-42. 